\title{
Nosema ceranae in South American Native Stingless Bees and Social Wasp
}

\author{
Martín Pablo Porrini ${ }^{1} \cdot$ Leonardo Pablo Porrini $^{1} \cdot$ Paula Melisa Garrido $^{1}$. \\ Carlos de Melo e Silva Neto ${ }^{2}$ • Darío Pablo Porrini ${ }^{3}$ - Fernando Muller ${ }^{4}$. \\ Laura Alejandra Nuñez ${ }^{5}$ Leopoldo Alvarez ${ }^{6}$. Pedro Fernandez Iriarte ${ }^{7}$. \\ Martín Javier Eguaras ${ }^{1}$
}

Received: 17 January 2017 / Accepted: 24 March 2017 / Published online: 7 April 2017

(C) Springer Science+Business Media New York 2017

\begin{abstract}
Besides the incipient research effort, the role of parasites as drivers of the reduction affecting pollinator populations is mostly unknown. Given the worldwide extension of the beekeeping practice and the diversity of pathogens affecting Apis mellifera populations, honey bee colonies are a certain source of parasite dispersion to other species. Here, we communicate the detection of the microsporidium Nosema ceranae, a relatively new parasite of honey bees, in stingless bees (Meliponini) and the social wasp Polybia scutellaris (Vespidae) samples from Argentina and Brazil by means of duplex PCR. Beyond the geographic location of the nests, $N$. ceranae was detected in seven from the eight Meliponini species analyzed, while Nosema apis, another common parasite of A. mellifera, was absent in all samples tested. Further research is necessary to determine if the presence of the parasite is also associated with established infection in host tissues.
\end{abstract}

Electronic supplementary material The online version of this article (doi:10.1007/s00248-017-0975-1) contains supplementary material, which is available to authorized users.

Martín Pablo Porrini

mporrini@mdp.edu.ar

1 Centro de Investigación en Abejas Sociales (CIAS), Facultad de Ciencias Exactas y Naturales, CONICET, Universidad Nacional de Mar del Plata, Funes 3350, 7600 Mar del Plata, Buenos Aires, Argentina

2 Instituto Federal de Educação, Ciência e Tecnólogia de Goiás, Quartel do XX, Praça Brasil Ramos Caiado, 76600.000, Goiás, Brazil

3 GENEBSO, INBIOTEC, UNMdP, CONICET, Funes 3350, 7600 Mar del Plata, Argentina
The obtained information enriches the current knowledge about pathologies that can infect or, at least, be vectored by native wild pollinators from South America.

Keywords Stingless bee $\cdot$ Polybia scutellaris . Microsporidia $\cdot$ Nosema apis

Recent studies have suggested that Apis mellifera L. hives represent a source of pathogens for other bee species such as solitary bees [1], bumble bees [2, 3], and stingless bees [4]. However, there is still insufficient information about the distribution and impact of honey bee diseases on native Hymenoptera populations.

Given a host-jump event from its historical host and a surprisingly late discovered territorial expansion, Nosema
4 Centro de Cría y mejoramiento de abejas "Erich Karl Faltus", N ${ }^{\circ}$ 111009, Calle J. M. Estrada №210, N3233 Capioví, Argentina

5 Laboratorio de Industrias Alimenticias, Universidad Nacional del Chaco Austral, Cdte. Fernandez 755, 3700 Pres. R. Sáenz Peña, Argentina

6 División Entomología, Museo de La Plata, CONICET, Universidad Nacional de La Plata, Edificio Anexo Museo, Unidades de Investigación FCN yM, 122 y 60, 1900FWA La Plata, Argentina

7 Laboratorio de Genética, Dto. de Biología, CONICET, UNMdP, Funes 3350, 7600 Mar del Plata, Argentina 
ceranae has demonstrated to be an epidemiologically relevant parasite affecting A. mellifera colonies [5-7]. Furthermore, there is a large discussion in course related to the role of this parasite in honey bee colony collapse disorder as reviewed by Holt and Grozinger [8].

Nosema ceranae spores are highly resistant [9] and spread as a consequence of the oral-fecal cycle, contaminating pollen, honey, hive materials, and the surrounding areas of the hive because of the wide working range of foragers [10-13] including also the dispersion throughout certain insectivorous birds [14]. Spreading pathways of spores and common use of resources enlarge the possibilities to reach other nectarivorous pollinators. Among them, stingless bees (Meliponini) and the social wasp Polybia scutellaris (White) (Vespidae) have been observed to perform robbing behavior to honey bee empty combs with traces of honey, commonly available in apiaries after harvest season, being also common the honey bee robbing from stingless bees destroyed nests (F. Muller and Dr. Porrini D., pers. obs.).

Meliponini comprises a tribe with nearly 600 species with distribution on tropical and subtropical regions of the world and on template regions of Southern hemisphere $[15,16]$. In Argentinian territory, 37 species are known to be present (Alvarez L. et al. data not published) with major representation in Misiones Province and in the Yungas region [17], while in Brazil, a huge diversity is present, since more than 300 species were described [18]. The social wasp P. scutellaris presents a wide distribution in Argentina [19]. They are animals of prey, although references indicate that wasps and honey bees commonly share floral resources [20] since they also collect large quantities of nectar [21].
Table 1 Detail of bees and wasp species analyzed, geographical origin, sampling date, and PCR results. Argentinian samples (stingless bees) were obtained from Chaco Province, Sáenz Peña city $\left(26^{\circ} 47^{\prime} 27^{\prime \prime} \mathrm{S}\right.$, $\left.60^{\circ} 26^{\prime} 29^{\prime \prime} \mathrm{W}\right)$; Misiones Province, Puerto Rico city $\left(26^{\circ} 49^{\prime} 30.5^{\prime \prime} \mathrm{S}\right.$, $\left.55^{\circ} 01^{\prime} 44.2^{\prime \prime} \mathrm{W}\right)$, and Capioví city ( $\left.26^{\circ} 56^{\prime} 40.8^{\prime \prime} \mathrm{S}, 55^{\circ} 02^{\prime} 63.1^{\prime \prime} \mathrm{W}\right)$; Polybia scutellaris wasp samples were obtained from Buenos Aires Province, Mar del Plata city ( $37^{\circ} 56^{\prime} 41^{\prime \prime} \mathrm{S}, 57^{\circ} 46^{\prime} 51^{\prime \prime} \mathrm{W}$ ). Brazilian samples were obtained from Goiás State, Goiânia city $\left(16^{\circ} 35^{\prime} 16.1^{\prime \prime} \mathrm{S}\right.$; $\left.49^{\circ} 17^{\prime} 32.7^{\prime \prime} \mathrm{W}\right)$. From each hive or nest, 30-40 individuals were collected in sterile flasks and stored in $90 \%$ ethanol for transportation until analyses. Wasp individuals were collected and freeze $\left(-18{ }^{\circ} \mathrm{C}\right)$ until analyses. Ten or 20 bees from each sample were pooled and macerated to obtain a filtered clean pellet to perform DNA extraction (High Pure PCR template preparation kit, Roche). The 16S rRNA locus was used to perform N. apis-N. ceranae duplex PCR according to MartínHernández et al. [41]. Negative controls (from DNA extraction) were included in all PCR experiments. Amplification products were visualized by electrophoresis in $2 \%$ agarose gel. To perform the PCR gel, $N$. ceranae-positive control, $N$. ceranae $+N$. apis co-infection sample, and a negative control sample were included. For further information see Supplementary Material
Species "common native name" Location/nest emplacement or nesting substrate

Argentina, Misiones, Capioví/hive in Kaki tree (Diospyros kaki)

Argentina, Misiones, Puerto Rico/hive in trunk

Argentina, Misiones, Capioví/hive in Kaki tree (Diospyros kaki)

Argentina, Chaco, S. Peña/hive in urban tree (Ceibo tree-Erythrina crista-galli)

Argentina, Chaco, S. Peña/rural, trunk of Quebracho tree-Schinopsis lorentzii

Argentina, Chaco, S. Peña/wooden (pine) rational hive box

Argentina, Chaco, S. Peña/rural zone, trunk

Argentina, Chaco, S. Peña/wooden (pine) rational hive box

Brasil, Goiás, Goiânia/wooden (Cedrela spp.) rational hive box

Brasil, Goiás, Goiânia/wooden (Cedrela spp.) rational hive box

Brasil, Goiás, Goiânia/wooden (Cedrela spp.) rational hive box

Brasil, Goiás, Goiânia/wooden (Cedrela spp.) rational hive box

Brasil, Goiás, Goiânia/wooden (Cedrela spp.) rational hive box

Brasil, Goiás, Goiânia/wooden (Cedrela spp.) rational hive box

Argentina, Buenos Aires, Mar del Plata, Natural Reserve "Laguna de los Padres"
Sampling year $\quad$ N. ceranae gel result (no. of pooled individuals)
2014

2014

2014

2015

2015

2015

2015

2015

2015

2015

2015

2015

2015

2015

2010
Positive (20)

Positive (20)

Positive (20)

Positive (20)

Positive (20)

Positive (10)

Positive (10)

Positive (20)

Negative (20)

Positive (10)

Positive (10)

Positive (10)

Positive (10)

Positive (10)

Positive (20) 
Given the close phylogenetic relation of Meliponini to Apini [22], the overlap in the spatial distribution range and feeding resources, the forager and robbing behavior of stingless bees and wasps, and the previous report of honey bee diseases in Meliponini species [4], the objective of this study was to assess $N$. ceranae presence on those native pollinators sampled from different South American sites. Fourteen stingless bee samples and one Polybia wasp were analyzed by means of duplex PCR. Details about species identification, analysis technique, sampling areas, and number of individuals are described in Table 1. PCR products whose length matched with those expected for $N$. ceranae (218 bp) were purified and then sequenced. The alignments of the sequences obtained are shown in Supplementary Material. In the present work, the duplex PCR analyses performed using primers for $16 \mathrm{~S}$ ribosomal RNA (rRNA) locus on pooled samples of hole bodies revealed the solely presence of $N$. ceranae in seven from the eight screened Meliponini species and in the sample of Polybia wasps. These results constitute the first detection of a Nosematidae parasite on samples of those native Hymenoptera.

An increasing number of studies reveal the occurrence of Microsporidian species, or specifically $N$. ceranae in wild pollinators, such as bumblebees [2, 3, 23, 24], wasps, and solitary bees [25]. Nevertheless, our results contrast with recent data from a survey performed in two Brazilian states, where a large number of Meliponini samples, analyzed for Nosematidae presence using primers for 18S rRNA locus, resulted in absence of detection [4]. In the cited work, most of the species sampled were different from the included in our work, being Tetragonisca fiebrigi (Schwarz), the only common species included in both works being positive to $N$. ceranae in our survey. Contradictory results could be clarified by larger studies, expanding the prospected area, the number of species and individuals sampled in different seasons. Furthermore, differences in molecular detection protocols should be attended.

Given the relatively long presence of $N$. ceranae in South America [26-28] and the widespread capability of the disease, there are many possible ways of interaction driving the contact between honey bees and native species resulting in cross contamination, since flowers are known to be an important site for interspecies transmission of bee pathogens [29, 30]. Also, robbing food resources is a common way of disease transmission between bee colonies [31, 32], being suggested as the cause of host-jump of $N$. ceranae between A. mellifera and Apis cerana colonies [33]. In the same way, some stingless bee species have evolved to a diverse robbing and usurping lifestyles, particularly stealing resources from other stingless bees and occasionally from honey bee nests [34-37]. Given that nests of stingless bees sampled from Misiones Province (Argentina) and Polibya wasp were settled near productive or feral honey bee hives, we propose the interspecies robbing behavior as a certain possibility of contact with $N$. ceranae spores. Nevertheless, sampled colonies from Brazil and Chaco Province (Argentina) were settled far away of the presence of managed honey bee hives and the sampling sites were surrounded mainly by native vegetation, and therefore, it is probable that another way of contact with spores could occur.

In reference to the other Nosema parasite, the absence of Nosema apis-positive results in our samples is consistent with reports indicating an absence of this species in South America [7, 26, Porrini M. et al., unpublished] or some scarce coinfection on isolated sites [27].

Pathological effects of $N$. ceranae in honey bees and bumble bees have been described [38-40]. Plischuk and Lange [2, 3] have already reported the presence of this microsporidium in bumble bees, infecting four native South American species, describing also spores inside epithelial midgut cells. Here, we report the first detection of $N$. ceranae in stingless bees and wasp samples of pooled individuals, but procedures do not allow us to determine if positive samples comprise a vector role of the insects, established infection in the host tissues, or both possibilities. Therefore, the invasion of host organs and possible effects on survival should be properly studied to test the hypothesis of the existence of a genus barrier which prevents the development of an intracellular infection or instead to describe a new host-jump of $N$. ceranae from honey bees to wild native stingless bees and wasps.

Acknowledgements The authors would like to thank Raquel Martín Hernández for technical assistance. This study was supported by the Consejo Nacional de Investigaciones Científicas y Técnicas (CONICET) and Agencia Nacional de Promoción Científica y Tecnológica (PICT 2014-394). Reviewer's comments have been really useful.

\section{Compliance with Ethical Standards}

Conflict of Interest The authors declare that they have no conflict of interest.

\section{References}

1. Ravoet J, De Smet L, Meeus I, Smagghe G, Wenseleers T, de Graaf DC (2014) Widespread occurrence of honey bee pathogens in solitary bees. J. Invertebr. Pathol. 122:55-58

2. Plischuk S, Martín-Hernández R, Prieto L, Lucía M, Botías C, Meana A, et al (2009) South American native bumblebees (Hymenoptera, Apidae) infected by Nosema ceranae (Microsporidia), an emerging pathogen of honey bees (Apis mellifera). Environ. Microbiol. Rep. 1:131-135

3. Plischuk S, Lange CE (2016) Bombus brasiliensis Lepeletier (Hymenoptera, Apidae) infected with Nosema ceranae (Microsporidia). Rev. Brasil. Entomol. 60(4):347-351. doi:10. 1016/j.rbe.2016.06.003 
4. Nunes-Silva P, Piot N, Meeus I, Blochtein B, Smagghe G (2016) Absence of Leishmaniinae and Nosematidae in stingless bees. Sci. Rep. 6:32547

5. Higes M, Martín-Hernández R, Meana A (2006) Nosema ceranae, a new microsporidian parasite in honey bees in Europe. J. inverteb. Pathol. 92:93-95

6. Huang W, Jiang J, Chen Y, Wang C-H (2007) A Nosema ceranae isolate from the honey bee Apis mellifera. Apidologie 38:30

7. Klee J, Besana AM, Genersch E, Gisder S, Nanetti A, Tam DQ, et al (2007) Widespread dispersal of the microsporidian Nosema ceranae, an emergent pathogen of the western honey bee, Apis mellifera. J. Invert. Pathol. 96(1):1-10

8. Holt HL, Grozinger CM (2016) Approaches and challenges to managing Nosema (Microspora: Nosematidae) parasites in honey bee (Hymenoptera: Apidae) colonies. J. Econ. Entomol. 109(4):14871503

9. Fenoy S, Rueda C, Higes M, Martín-Hernández R, del Aguila C (2009) High-level resistance of Nosema ceranae, a parasite of the honey bee, to temperature and desiccation. Appl. Environ. Microbiol. 75:6886-6889

10. Carmo RM, Franceschinelli EV, Silveira FA (2004) Introduced honey bees (Apis mellifera) reduced pollination success without affecting the floral resource taken by native pollinators. Biotrop 36:371-376

11. Higes M, Martín-Hernández R, Garrido-Bailón E, García-Palencia P, Meana A (2007b) Detection of infective spores in corbicular pollen of forager honey bees. J. Invertebr. Pathol. 97:76-78

12. Higes M, De la Rua P (2014) Presence of Nosema ceranae associated with honey bee queen introductions. Infect. Genet. Evol. 23: 161-168

13. Mutinelli $\mathrm{F}$ (2011) The spread of pathogens through trade in honey bees and their products (including queen bees and semen): overview and recent developments. Revue scientifique et technique de 1'Office international des Epizooties 30:257-271

14. Higes M, Martín-Hernández R, Garrido-Bailón E, Botías C, GarcíaPalencia P, Meana A (2008) Regurgitated pellets of Merops apiaster as fomites of infective Nosema ceranae (Microsporidia) spores. Environ. Microbiol. 10(5):1374-1379. doi:10.1111/j.14622920.2007.01548

15. Michener CD (2007) The bees of the world, 2nd edn. Johns Hopkins University Press, Baltimore xvi+[i]+953 pp.,+20 pls

16. Rasmussen C, Cameron SA (2010) Global stingless bee phylogeny supports ancient divergence, vicariance, and long distance dispersal. Biol. J. Linn. Soc. 99:206-232

17. Roig-Alsina A, Vossler FG, Gennari P (2013) Stingless bees in Argentina. In: Pot honey: a legacy of stingless bees. Lugar, New York, pp. 125-134

18. Camargo JMF, Pedro SRM (2007) Meliponini Lepeletier, 1836. In: Moure JS, Urban D, GAR M (eds) Catalogue of bees (Hymenoptera, Apoidea) in the neotropical region. Sociedade Brasileira de Entomologia, Curitiba 1058 pp

19. Willink A (1951) Los Véspidos sociales argentinos, con exclusi6n del género Mischocyttarus (Hym. Vespidae). - Ada Zool. Lilloana 59(4):139-157

20. Telleria MC (1996) Plant resources foraged by Polybia Scutellaris (Hym. Vespidae) in the Argentine Pampas. Grana 35:302-307

21. Schwarz HF (1929) Honey wasps. Nat. Hist. 29:421-426

22. Brothers DJ (1999) Phylogeny and evolution of wasps, ants and bees (Hymenoptera, Chrysidoidea, Vespoidea and Apoidea). Zool. Scr. 28:233-250
23. McIvor CA, Malone LA (1995) Nosema bombi, a microsporidian pathogen of the bumble bee Bombus terrestris L. N Z J Zool 22:2531

24. Li J, Chen W, Wu J, Peng W, An J, Schmid-Hempel P, et al (2012) Diversity of Nosema associated with bumblebees (Bombus spp.) from China. Int. J. Parasitol. 42:49-61

25. Evison SEF, Roberts KE, Laurenson L, Pietravalle S, Hui J, et al. (2012) Pervasiveness of parasites in pollinators. PLoS One 7(1). doi: e30641

26. Invernizzi C, Abud C, Tomasco IH, Harriet J, Ramallo G, Campa J, Katz H, et al (2009) Presence of Nosema ceranae in honey bees (Apis mellifera) in Uruguay. J. Invertebr. Pathol. 101:150-153

27. Medici SK, Sarlo EG, Porrini MP, Braunstein M, Eguaras MJ (2012) Genetic variation and widespread dispersal of Nosema ceranae in Apis mellifera apiaries from Argentina. Parasitol. Res. 110:859-864

28. Teixeira EW, dos Santos LG, Sattler A, Message D, Alves MLTMF, Martins MF, et al (2013) Nosema ceranae has been present in Brazil for more than three decades infecting Africanized honey bees. J. Invertebr. Pathol. 114:250-254

29. Singh R, Levitt AL, Rajotte EG, Holmes EC, Ostiguy N et al. (2010) RNA viruses in hymenopteran pollinators: evidence of inter-taxa virus transmission via pollen and potential impact on non-Apis hymenopteran species. PLoS One 5(12). doi: e14357

30. Graystock P, Goulson D, Hughes WOH (2015) Parasites in bloom: flowers aid dispersal and transmission of pollinator parasites within and between bee species. Proc. R. Soc. B Biol. Sci. 282:20151371

31. Lindström A, Korpela S, Fries I (2008) Horizontal transmission of Paenibacillus larvae spores between honey bee (Apis mellifera) colonies through robbing. Apidologie 39:515-522

32. Grüter C, von Zuben LG, Segers FHID, Cunningham JP (2016) Warfare in stingless bees. Insect. Soc. 63:223

33. Huang WF, Bocquet M, Lee KC, Sung IH, Jiang JH, Chen YW, Wang CH (2008) The comparison of rDNA spacer regions of Nosema ceranae isolates from different hosts and locations. J. Invertebr. Pathol. 97:9-13

34. Müller F (1874) The habits of various insects. Nature 10:102-103

35. Michener CD (1946) Notes on the habits of some Panamanian stingless bees (Hymenoptera, Apidae). J N Y Entomol Soc 54: 179-197

36. Sakagami SF, Laroca S (1963) Additional observations on the habits of the cleptobiotic stingless bees, the genus Lestrimelitta friese (Hymenoptera, Apoidea). J. Fac. Sci. Hokkaido Univ. 15: 319-339

37. Roubik DW (1989) Ecology and natural history of tropical bees. Cambridge Univ. Press, New York 514 pp

38. Paxton RJ, Klee J, Korpela S, Fries I (2007) Nosema ceranae has infected Apis mellifera in Europe since at least 1998 and may be more virulent than Nosema apis. Apidologie 38:558-565

39. Higes M, García-Palencia P, Martín-Hernández R, Meana A (2007a) Experimental infection of Apis mellifera honey bees with the Microsporidia Nosema ceranae. J. Invertebr. Pathol. 94:211217

40. Graystock P, Yates K, Darvill B, Goulson D, Hughes WOH (2013) Emerging dangers: deadly effects of an emergent parasite in a new pollinator host. J. Invert. Pathol. 114:114-119

41. Martín-Hernández R, Meana A, Prieto L, Martínez-Salvador A, Garrido-Bailón E, Higes M (2007) Outcome of colonization of Apis mellifera by Nosema ceranae. Appl Environ Microbiol 73: $6331-6338$ 